Vedecký príspevok/Scientific Article

Recenzované/ Review: 20. 12. 2021

https://doi.org/10.24040/eas.2021.22.2.114-133

\title{
Vybrané aspekty spoločenskej funkcie ekonómie v súčasnosti
}

Selected aspects of social function of economics in contemporary society

\section{Jana Marasová, Žaneta Lacová}

Abstract: Príspevok má ambíciu zdôraznit’ význam ekonómie ako spoločenskej vedy, poukázat' na dôležitost’ jej kontinuálneho poznávania v ekonomickom vzdelávani a identifikovat' motiváciu dnešnej generácie mladých l'udí na toto vzdelávanie. Ciel'om príspevku je určit' klúčové dimenzie spoločenskej funkcie ekonómie v súčasnej slovenskej spoločnosti. Autori sa pri naplñaní uvedeného ciel'a opierajú o výsledky riešených univerzitných projektov a vlastné skúsenosti z výučby ekonomickej teórie, o existujúce relevantné zdroje a prieskumy danej problematiky, ako aj o uskutočnený vlastný prieskum $v$ komparácii výsledkov $s$ medzinárodným výskumom CORE. V prvej časti príspevku poukazujú na špecifiká ekonómie a na vybrané otázky ekonomického vzdelávania, v druhej sa venujú dimenziám spoločenskej funkcie ekonómie a výsledkom realizovaného výskumu. Vzávere sumarizujú skutočnosti, ktorými ekonomická veda prispieva k rozvoju kritického myslenia jednotlivcov, $k$ sebareflexii spoločnosti a k obrane jej demokratických hodnôt.

Key words: funkcia ekonómie, postavenie v spoločnosti, ekonomické vzdelávanie, motivácia študentov

JEL Classification: A10, A11, A12

\section{Úvod}

Na Slovensku sa už niekol'ko rokov poukazuje na to, že veda a výskum sú v tejto krajine dlhodobo poddimenzované a nedoceňované (ESET ScienceAward, 2019; SOVVA, 2021)). Výrazne sa to prejavuje najmä na postavení spoločenských a humanitných vied, ako to vyplýva z Memoranda ich predstavitel’ov (2016), ale i d’alších analýz (Bátora, 2016; Drábik, Kšiňan, 2017). Danou problematikou sa zaoberá aj univerzitný projekt APVV-18-0122, $\mathrm{v}$ rámci ktorého bol spracovaný tento príspevok.

Našim ciel’om je na základe doteraz dosiahnutých výsledkov riešenia projektu poukázat' na význam ekonómie ako spoločenskej vedy i na úlohu ekonomického vzdelávania, a následne prezentovat' výsledky vlastného prieskumu postoja študentov k vybraným otázkam 
ekonómie ako aj k ich motivácii na štúdium ekonómie, a to v komparácii so závermi iných uskutočnených výskumov. Sústred’ujeme sa pritom na viaceré dimenzie spoločenskej funkcie ekonomickej vedy a tiež na postavenie a úlohu samotných ekonómov, ktorí by mali byt' nositel'mi jej najnovších poznatkov, ale aj expertmi na praktickú hospodársku politiku. Čast' ekonómov, pôsobiacich $\mathrm{v}$ akademickom prostredí, by tieto svoje zručnosti mala pretavovat' smerom $\mathrm{k}$ diverzifikácii obsahu i metód výučby ekonómie súčasnej generácii študentov. V súvislosti s ekologickými a sociálnymi imperatívmi dnešnej doby si kladieme aj otázku, či by ekonómovia nemali byt' razantnejší pri hl'adaní a presadzovaní alternatívnej podoby ekonomického života.

Spoločenský význam ekonomickej vedy demonštrujeme na jej prínose k rozvoju kritického myslenia jednotlivcov, ku kultivácii verejného diskurzu a s ním spojenej sebareflexii spoločnosti, ale aj k obrane základných demokratických hodnôt, kde je úloha spoločenských vied vo všeobecnosti nespochybnitel’ná.

\section{1 Špecifiká ekonomickej vedy a jej novodobá genéza}

Pojem spoločenské vedy býva vymedzený rôzne, v závislosti od viacerých kritérií (Ondrejkovič, 2010). Podl’a Centrálneho informačného portálu Ministerstva školstva, vedy, výskumu a športu SR (https://www.vedatechnika.sk) sa do platnej slovenskej legislatívy premietla definícia Organizácie pre hospodársku spoluprácu a rozvoj, ktorá pod daný pojem zahŕňa predovšetkým vedné disciplíny psychologické, ekonomické, pedagogické, sociálne, právne a politické. Každá z nich má svoje následné podrobnejšie členenie a špecifické charakteristiky. Spoločenské vedy teda predstavujú široké spektrum vedných odborov, ktoré sa v mnohom odlišujú, ale aj doplńajú, a ktoré majú viac či menej výrazný spoločenskohospodársky význam. Ekonómia ako spoločenská veda má svoje špecifiká, ktoré následne determinujú jej úlohu v spoločnosti.

\section{1 Špecifické charakteristiky ekonómie}

Ako všetky spoločenské vedy, aj ekonómia čelí t’ažkostiam pri formulovaní jednoznačných vedeckých záverov, čo vyplýva zo skutočnosti, že predmetom jej výskumu je l'udské rozhodovanie a správanie, ktoré je a priori slobodné a spontánne, čím sa vymyká všeobecným pravidlám. Ekonómia má naviac svoje vlastné zvláštnosti, ktoré Guerrien (2004) zdôvodnil nasledovne: 
- Skúma vzt'ahy medzi l'ud'mi, ktoré je t’ažké, lepšie povedané nemožné redukovat' na presné závislosti medzi izolovanými premennými, z čoho zároveň vyplýva, že v ekonómii sa nedajú uskutočňovat' kontrolované experimenty, aké sú bežné v exaktných vedách.

- Ak aj ekonomická teória odhalí relatívne spol'ahlivé korelácie medzi určitými premennými, takmer nikdy nie sú ani univerzálne ani trvácne, pretože sa menia v priestore i čase: neplatia rovnako $\mathrm{v}$ jednotlivých regiónoch sveta ani $\mathrm{v}$ jednotlivých časových obdobiach. V ekonómii neexistujú presné zákony prírodných vied, predmetom jej výskumu sú skôr tendencie vývoja analyzovaných premenných.

- Teoretik, či už si to uvedomuje alebo nie, je zainteresovaným subjektom spoločnosti, resp. ekonomiky, ktorú skúma, a má svoju predstavu, ako ich zlepšit' i ako sa určité zlepšenie dá dosiahnut'. V prípade ekonómie je táto normatívna dimenzia vel'mi výrazná a často býva aj zdrojom nedorozumení, pretože teórie nie vždy dostatočne jasne ukazujú, ako modely, o ktoré sa opierajú, zapadajú do danej perspektívy. Galbraith (2003) dokonca pokladá rady niektorých predstavitel'ov dominantného mainstreamu adresované tvorcom hospodárskej politiky, ako aj ich zdôvodnenia, za „vlažné“. Odporúčania týchto ekonómov sú skôr ozvenou vel'kých myšlienok z minulosti než originálnymi návrhmi na riešenie mnohých vážnych ekonomickosociálnych otázok, ktoré prináša súčasnost’.

Uvedené špecifické charakteristiky ekonómie sa viac či menej profilovali v jej historickej genéze. Poznanie minulosti ekonomickej vedy je dôležité pre vysvetlenie jej súčasného postavenia $\mathrm{v}$ spoločnosti, pre predvídanie jej budúceho vývoja a tiež pre pochopenie spoločenského významu, ktorý predstavuje. Preto je už v procese vzdelávania budúcich ekonómov extrémne dôležité vracat' sa ku koreňom ekonómie a spoznávat' jej následný vývoj v jednotlivých ekonomických doktrínach, v časovom i hospodárskom kontexte, v ktorom vznikali, a v myšlienkových postupoch ich hlavných predstavitel'ov. Poznat' dejiny ekonomických teórií je pre ekonómov ale aj manažérov nepochybne rovnako dôležité ako poznanie rímskeho práva pre budúcich právnikov.

Podl'a Boyer (2003) sa dajú rozlíšit' tri kategórie ekonómov, ktorých prístupy sa v určitej súčinnosti výrazne prejavili najmä v 60. rokoch 20. storočia. Prvou z nich sú ekonómovia, ktorí sa využitím aj matematických metód snažili ukázat', ako je možné v hospodárstve dosiahnut' všeobecnú ekonomickú rovnováhu. Ich výskumy vyúst’ujú do demonštrácie ekonómie blahobytu, ktorá mala ukázat', za akých podmienok je pôsobenie neviditel'nej ruky trhu opodstatnené. Najvýznamnejšími predstavitel'mi daného prístupu sú P. Samuelson a W. Nordhaus. Zo záverov výskumných prác tejto skupiny ekonómov však vyplynulo aj to, že je 
vel'mi t’ažké zovšeobecňovat' podmienky životaschopnosti trhovej ekonomiky, a že všeobecná ekonomická rovnováha je teória vel'mi relatívna, čo potvrdilo predovšetkým obdobie stagflácie v 70. rokoch.

Druhú kategóriu ekonómov predstavujú ekonometrici, ktorí po keynesiánskej revolúcii začali využívat' štatistické postupy a techniky na spracovanie chronologických sérií dát z národného účtovníctva s ciel'om odhalit' významné korelácie a kauzality, ktoré by umožnili predvídat' d’alší vývoj ekonomiky. Na vypracovaných ekonometrických modeloch práve týchto ekonómov vznikla tzv. keynesiánska aplikovaná makroekonómia, o ktorú sa následne opierali tvorcovia hospodárskej politiky. Za hlavného predstavitel'a tejto makroekonómie možno pokladat' nositel'a Nobelovej ceny z roku 1980 Lauwreca Kleina. Po vel'mi dobrých výsledkoch uplatňovania daných modelov v 60. rokoch došlo v d'alšom desat'ročí $\mathrm{k}$ ich významnej relativizácii spôsobenej všeobecným zhoršením ekonomických ukazovatel'ov nárastom inflácie, nezamestnanosti a stagnáciou hospodárstva.

Tretiu skupinu ekonómov profilujúcu sa v období 60. rokov Boyer (2003, s. 60) nazýva sociálnymi inžiniermi hospodárskej politiky. Ich úlohou je pridel'ovat' existujúce nástroje, orgánom verejnej moci a správy, aby mohli ovplyvňovat' realizáciu hlavných národohospodárskych ciel’ov v štyroch známych oblastiach: dosahovanie ekonomického rastu, vysokej, resp. plnej zamestnanosti, stabilnej cenovej hladiny a vyrovnaný zahraničný obchod.

Uvedené tri skupiny ekonómov súbežne a v doplňujúcej sa súčinnosti od vzniku keynesiánskej teórie t’ažili z rozvoja štatistických techník a matematických možností merania ekonomických premenných a reprezentovali ekonómiu ako relatívne celistvú, ktorá vie ekonomické súvislosti pochopit', predvídat' a poskytovat' rady na žiadúce ovplyvňovanie hospodárskych procesov. Táto celistvost' však nemala dlhé trvanie, pretože hospodársky vývoj v 70. ale i v 80. rokoch poukázal na jej nereálnost'. Vznikli mnohé nové a prevažne konfrontačné koncepcie patriace do širokého spektra od keynesiánstva až po neoschumpeteriánstvo. Hospodárske politiky, ktoré sa na ich základe odvtedy vytvárajú, neodrážajú pokrok ekonomického poznania, ale predstavujú kompromisy politických koalícií pri riešení tém ich volebných programov, pričom diskusie ekonómov sa často obmedzujú na konfrontácie týkajúce sa vzt’ahu trhu a štátu a predovšetkým priestoru pre ich činnost' v ekonomike. Z tohto hl'adiska je možné povedat', že ekonómovia viac-menej stratili neutralitu a prestali byt' hovorcami svojej vedy, čo mohlo výrazne narušit' vnímanie ich postavenia $\mathrm{v}$ spoločnosti. 


\subsection{Vybrané otázky spoločenskej funkcie ekonómie}

Ekonómia má okrem prakticko-hospodárskej úlohy aj zodpovednú spoločenskú funkciu vychádzajúcu z formovania mladej generácie prostredníctvom študentov ekonómie. Teoretická rôznorodost', typická pre každú spoločenskú vedu, sa prirodzene odráža aj v príslušnom vzdelávacom procese. Výučba ekonómie v podmienkach Slovenska aj ostatných postkomunistických krajín doteraz trpí tým, že bola počas štyroch desat'ročí odtrhnutá od svojich koreňov. V začiatkoch 90. rokov sa museli najprv samotní vysokoškolskí učitelia oboznámit’ s cestou, ktorú ekonómia ako vedná disciplína za ten čas prešla, a kam sa posunulo ekonomické vzdelávanie. Celkom prirodzene pri výučbe siahli po prvých dostupných preložených učebniciach ekonómie. Najprv to bola Ekonómia od autorov P. A. Samuelson a W. D. Nordhaus (1992), následne Zásady ekonómie od N. G. Mankiw (1999). Štúdiom týchto a postupne d’alších knižných publikácií si pedagógovia otvárali mysel' novým aktuálnym ekonomickým poznatkom a skúmaným súvislostiam, na ktorých si vybudovali vlastné metodologické postupy výučby a vypracovali svoje učebné materiály.

Paralelne s vývojom ekonómie vo svete sa začali tieto základné učebnice tzv. ortodoxnej ekonomickej teórie $\mathrm{v}$ západnom svete dopĺn̆at' o nové alternatívne podoby učebníc. Hospodárstvo a ekonomický vývoj všeobecne sa za posledných 30 rokov podstatne zmenili, a ekonómii nastolili nové otázky, ktoré bolo a stále je potrebné riešit', a na ktoré predstavitelia spomínanej ortodoxnej, resp. tradičnej teórie nemajú jednoznačné odpovede. Aj preto sa ekonómom vyčítajú nejasné a nejednoznačné postoje k súčasným urgentným otázkam, akými sú napr. záchrana životného prostredia, znižovanie chudoby, či podpora novej podoby ekonomiky, ktorá bude s vel'kou pravdepodobnost'ou nevyhnutným dôsledkom súčasnej pandemickej krízy i doteraz neriešených viacerých sociálnych a ekologických otázok. Hoci základný ekonomický zákon vzácnosti naznačuje, že zmena ekonomického myslenia a spôsobu výroby i spotreby sa stáva imperatívom, hlasy ekonómov i tvorcov hospodárskej politiky sú $\mathrm{v}$ tomto smere sotva počutel'né.

Protipandemické opatrenia a lockdowny posledných dvoch rokov spôsobili bezprecedentný pokles produkcie, a vlády jednotlivých štátov vynakladajú obrovské prostriedky na pomoc podnikom, aby zabránili ich kaskádovitému krachu a obnovili doterajší kapitalistický spôsob výroby. „Zachránit’ ekonomiku“ takú, aká bola, sa stáva prvoradým ciel'om, avšak máloktorý ekonóm ponúka pripravené scenáre, ktoré by pomohli zachránit' planétu. Borrits (2020) sa pýta, či by sme takúto cestu nemali zamietnut' a začat' sa zamýšl'at' nad možnost'ou budovania inej alternatívnej podoby ekonomiky. Či by ekonómovia nemali 
namiesto výpočtov úrokov, ktoré budú zadlžené štáty roky splácat', razantne argumentovat’ v prospech spomal'ovania klimatických zmien a rozvoja progresívnych odvetví, než napr. podporovat' záchranu automobilového či leteckého priemyslu.

Tak ako sa váhavo a opatrne menia postoje ekonómov, tak vo väčšine prípadov zostávajú rovnaké aj zaužívané metódy výučby a „overené“ bibliografické zdroje tradičných autorov (Samuelson, Nordhaus, 2017; Mankiw et al., 2019; Bernanke et al., 2019; Stiglitz, 2015 a i.). $\mathrm{V}$ myšlienkových procesoch a reflexiách týchto nepochybne kvalitných učebníc už dnes nenájdeme adekvátne odpovede na ekologické a sociálne výzvy súčasného vývoja, úzko spojenými s ekonomickými výzvami, ale ani na potreby hospodárskopolitických subjektov, čo následne vedie k nekonzistentnej argumentácii (Juniper et al., 2021). V ekonómii je preto potrebné vytvárat' priestor pre pluralistickú výučbu a využivat' k tomu dnes už mnohé dostupné zdroje či už z behaviorálnej teórie, psychológie alebo zo socioekonómie paradigmy, ktorá predstavuje spojenie ekonomickej teórie so sociológiou, skúmajúcu vplyv l’udských vzt’ahov na ekonomický život. Ide o určitú racionalizáciu konceptualizácie ekonomických rozhodnutí. Poznanie alternatívnych ekonomických prístupov je zvlášt' dôležité v makroekonómii, ktorá je v mnohom kontroverznejšia ako mikroekonómia, pretože makroekonomické prostredie sa dynamicky mení. Spomínané ortodoxné učebnice dané zmeny vo svojom obsahu neodrážajú, alebo ak aj, tak až oneskorene v novších vydaniach. Typickým príkladom sú nové praktiky centrálnych bánk, relativita platnosti kvantitatívnej teórie peňazí či vplyvu úrokovej miery centrálnej banky na úrokové sadzby komerčných bánk. V týchto a iných príkladoch sa už treba odvolávat' skôr na skúsenosti príslušných národných či nadnárodných inštitúcií ako na tradičnú neoklasickú teóriu.

V tejto súvislosti sa však domnievame, že chýbajúci pluralizmus vo výučbe ekonómie nie je dôsledkom toho, že by pedagógovia nemali odvahu oboznamovat' študentov s existujúcimi alternatívnymi teóriami, ale skôr skutočnosti, že sme svedkami obmedzovania výučby ekonomickej teórie, dejín ekonomických teórií, či teórie medzinárodných ekonomických vzt'ahov. Otázkou zostáva, či dokážeme formovat' dobrých absolventov bez dostatočných konceptuálnych základov z ekonómie, t. j. poznatkov o zásadných ekonomických súvislostiach a zákonitostiach.

Potrebná inovácia a aktualizácia ekonomického vzdelávania vedie tiež k skutočnosti, že učitelia ekonómie intenzívne reflektujú aj to, ktoré ekonomické témy študentov viac zaujímajú a možno ich aj motivovali $\mathrm{k}$ výberu ich vysokoškolského štúdia. Typickým príkladom takýchto inovatívnych prístupov, ktorých ciel’om je efektívne využitie 
redukovaného priestoru pre vzdelávanie ekonomickej teórie, je učebnica tímu CORE z roku 2017 „The Economy, Economics for a changing world“. Prístup tímu autorov smeruje k zvýšenej motivácii študentov pre štúdium ekonomickej teórie, aby spoznávali jej pridanú hodnotu prostredníctvom rozvoja myslenia a pochopenia aktuálnych spoločenských problémov v témach, o ktoré majú záujem. Systém implementuje aj poznatky behaviorálnej a inštitucionálnej ekonómie, pričom takto vytvorená učebnica je aktuálna vo vzt’ahu k zmenám, ktoré v určitom kontexte či v širšom ekonomickom prostredí nastali. Na základe vlastných skúseností $\mathrm{z}$ aplikácie týchto prístupov $\mathrm{v}$ predmetoch Microeconomics a Macroeconomics na Ekonomickej fakulte UMB sa domnievame, že daný spôsob vzdelávania môže byt' vhodný najmä na začiatku štúdia ekonomickej teórie a je pre študentov dôležitý pre vytvorenie si vzt’ahu k ekonómii.

\section{Materiál a metódy skúmania}

Ambíciou nášho príspevku je zdôraznit' význam ekonómie ako spoločenskej vedy, poukázat' na dôležitost' jej kontinuálneho poznávania $\mathrm{v}$ ekonomickom vzdelávaní a zistit' motiváciu dnešnej generácie mladých l’udí pre toto vzdelávanie. Ciel’om príspevku je identifikovat' kl'účové dimenzie spoločenskej funkcie ekonómie v súčasnej slovenskej spoločnosti. Pri napĺňaní tohto ciel’a využívame jednak svoje skúsenosti s výučbou ekonomickej teórie, ale aj poznatky realizovaného prieskumu, a to v komparácii s dostupnými závermi podobných uskutočnených výskumov.

Vlastný prieskum sme realizovali v zimnom semestri akademického roka 2021/22 na Ekonomickej fakulte UMB pomocou dotazníka, ktorý sme distribuovali anonymne online formou študentom prvého ročníka fakulty vo všetkých študijných programoch. Študentov 1. ročníka sme si zvolili preto, že sú relevantnou skupinou v oblasti výberu štúdia ekonomických študijných programov, ked’že rozhodovací proces v tomto smere absolvovali nedávno. Ide o skupinu študentov, ktorí sa len oboznamujú s ekonomickou teóriou, preto ich z istého uhla pohl'adu možno považovat' za ešte „nezat’ažených“, t. j. citlivejších na očakávania spoločnosti od ekonómie a ekonómov.

Spomedzi 398 oslovených študentov 1. ročníka dotazník vyplnilo 77 z nich, pričom $73 \%$ respondentov tvorili študentky. V dotazníku sa študenti vyjadrovali k 7 výrokom týkajúcich sa ich motivácie pre štúdium ekonómie pomocou otázok so škálou (1- úplne súhlasím, 2 - skôr súhlasím, 3 - skôr nesúhlasím, 4 - úplne nesúhlasím a 5 - neviem/nechcem sa vyjadrit'). V druhej časti dotazníka študenti odpovedali na otázku ohl'adom spoločenských problémov, ktorými sa v súčasnosti podla nich má ekonomické skúmanie zaoberat'. Študenti si mohli 
zvolit’ maximálne tri z ponúkaných 30 tém. Ponuka tém vychádzala z prezentovaných výsledkov zahraničných štúdií (Core team, 2017). V rámci iniciatívy CORE učitelia ekonómie kladú svojim študentom rovnakú otázku a to „Aký najpálčivejší problém by mali ekonómovia vyriešit?“،. Tohto prieskumu sa zúčastňuje viac ako 8000 študentov zo 40 univerzít v 18 krajinách a údaje sú zozbierané od roku 2016. Náš prieskum na iniciatívu CORE nadväzuje a zist'uje preferencie študentov v slovenských podmienkach.

Pri naplńnaní stanoveného ciel’a zdôrazňujeme prirodzené a dnes už samozrejmé prepojenie ekonómie s ostatnými spoločenskými vedami. Vychádzame z predpokladu, že hoci ekonómia má svoju vlastnú silnú identitu, danú históriou a vel'kými osobnost’ami v nej, a rieši niektoré otázky, ktoré môže zodpovedat' len ona, vd’aka nástrojom, ktoré má k dispozícii, pri väčšine skúmaných ekonomických problémoch je závislá aj od poznatkov iných spoločenských vied. Napr. na analýzu vzt’ahu práce a vol’ného času s implikáciám pre pracovný trh potrebuje sociológiu, na skúmanie racionality jednotlivca psychológiu a na charakteristiku hospodárskeho kontextu v minulosti sa nezaobíde bez histórie.

\section{Výsledky a diskusia}

Výsledky nášho skúmania a s nimi súvisiacu diskusiu prezentujeme v dvoch častiach. V prvej porovnávame naše názory na spoločenskú funkciu ekonómie a ekonomického vzdelávania s názormi iných autorov, obsahom druhej časti je syntéza a interpretácia uskutočneného výskumu na vybranej vzorke študentov.

\subsection{Dimenzie spoločenskej funkcie ekonómie}

Za jednu z najdôležitejších dimenzií ekonomickej vedy v spoločnosti je treba pokladat' jej úlohu pri formovaní kritického myslenia jednotlivcov, čo viac-menej prirodzene vyplýva z predmetu jej výskumu - rieši otázky l'udského správania a rozhodovania, na ktoré síce nemá jednoznačné odpovede, ale zdôrazňovaním zákona vzácnosti vedie jednotlivcov i celú spoločnost' k racionalite a k výberu efektívnych možností, a to najmä tým, že upozorňuje na základné ekonomické súvislosti, ktoré z daného zákona vyplývajú, a ktoré sa nedajú obíst'. Ortodoxná neoklasická ekonómia v prepojení s alternatívnymi teóriami kritické myslenie jednotlivca rozvíja $\mathrm{v}$ širšom kontexte, pretože jeho vedomosti obohacuje o poznanie iných spoločenských vied. Otvorenost' voči postojom a názorom iných je nevyhnutnou podmienkou pre rozvoj kultivovaného verejného diskurzu.

Inou dimenziou spoločenskej funkcie ekonómie je jej prínos k sebareflexii jednotlivca a spoločnosti. Vysvetl'ovaním ekonomických javov v súvislostiach a v historickej genéze táto 
veda poukazuje na skutočné i potenciálne dôsledky každého rozhodnutia. Sebareflexia je podstatná pre podnikatel'ov vo vzt’ahu k ich profilu, schopnostiam, motivácie a ciel’ov ich podnikatel'ských projektov, aby boli úspešní, ale rovnako je dôležitá pre spotrebitel'ov, resp. domácnosti, ktorým ekonómia pripomína, že nemôžu mat' v živote všetko, a dáva im potrebné poznanie na výber najlepšej alternatívy v mnohých každodenných otázkach vol'by.

Kritické myslenie a kultivované verejné diskusie vyúst'ujú do d’alšej úlohy ekonómie ako spoločenskej vedy, a tou je obrana a rozvoj demokratických hodnôt. Najdôležitejšími z nich, ktoré ekonómia zdôrazňuje, sú slobodná vol'ba ekonomických subjektov z hl'adiska využívania disponibilných vzácnych zdrojov, a klúčová inštitúcia súkromného vlastníctva ako i právo na jeho ochranu. Tieto demokratické hodnoty sú základom podnikania, najmä zdravého prostredia malých a stredných podnikov, ktoré vedia najúčinnejšie odhal'ovat' nové podnikatel'ské príležitosti, prispievat' k ekonomickému rastu a tým k zvyšovaniu životnej úrovne obyvatel’ov. Stimulácia k podnikaniu je $\mathrm{v}$ tejto súvislosti jednou z podstatných dimenzií spoločenskej funkcie ekonomickej vedy.

Z uvedeného vyplýva, že ekonómia má nepochybne schopnost' prispievat' k zlepšeniu životných podmienok jednotlivcov i celej spoločnosti, napr. cez pôsobenie manažérov na svojich zamestnancov (Smutný, 2020), otázkou však zostáva, nakol'ko sa tento jej potenciál reálne využíva aj vo vzdelávacom procese. Závisí to od viacerých skutočností, ako napr. akí jednotlivci študujú ekonómiu, ako štúdium ekonómie prispieva k formovaniu profilu daných jednotlivcov, a akú dôveru, resp. nedôveru má verejnost' voči ekonómom, ktorí sa z týchto jednotlivcov stali.

Podl'a Bauman, R. (2009), je ekonomické vzdelávanie individuálnym i spoločenským zlom, pretože zo študentov, ktorí ho absolvujú, sa stávajú sebeckejšie a menej altruistické osobnosti v porovnaní s absolventmi iných odborov. Výsledky aj d’alších autorov (Delgado et al., 2020) vedú k záverom, že nadobúdaním ekonomického poznania a nazerania na svet čast' jednotlivcov stráca svoju ,nevinnost““. Dôsledkom toho je nielen negatívny dopad na spoločnost', ale aj ich nižší subjektívny materiálny a psychologický well-being. Treba tiež zdôraznit', že na základe predstavených záverov nie je možné jednoznačne odlíšit' proces učenia sa (ekonómovia sú sebeckejší, pretože ich k tomu vedie štúdium ekonómie) od procesu selekcie (štúdium ekonómie volia sebeckejšie osobnosti), ktorý popisujú Frey and Meier (2002).

Dané skutočnosti môžu viest' k pochybnostiam, či ekonomické vzdelávanie, ktoré je už dlhodobo principiálne založené na neoklasickej ekonómii a na modeli homo oeconomicus 
maximalizujúcom svoj zisk, resp. úžitok, je najvhodnejšie na formovanie ekonomického rozhodovania a správania. Viacerí autori (Horeháj, 2011, Galambaud, 2014, Ódor, 2021) zdôrazňujú, že sú to užitočné koncepty, pretože pripomínajú kl’účové zákonitosti a súvislosti ekonomických vzt’ahov. Ak sa správame racionálne, ak sa podnikatel' snaží efektívne využit' obmedzené disponibilné zdroje a spotrebitel' sa usiluje dosiahnut' zo svojich rovnako obmedzených prostriedkov o čo najvyššiu úroveň uspokojovania potrieb, je to nepochybne prejav porozumenia ekonomických zákonitosti, rešpektovania zákona vzácnosti a napíňania individuálneho záujmu, z ktorého prosperuje celá spoločnost'. Tieto koncepty je však potrebné vysvetl'ovat' s dôrazom na širšie súvislosti, napr. do nákladov treba okrem priamych peňažných nákladov explicitne zahrnút' aj hodnotu negatívnych dôsledkov v environmentálnej oblasti či voblasti narušenia sociálnych väzieb. Domnievame sa, že pri výučbe mikroekonómie nepostačuje študentov len odkázat' na koncept alternatívnych nákladov, ale konkrétne príklady na ilustráciu rozhodovania jednotlivcov (spotrebitelov) či podnikov by mali v sebe obsahovat' aj tieto spoločenské dimenzie.

Autori d’alšieho výskumu (Gerlach, 2017) zdôrazňujú, že študenti ekonómie majú podobné vnímanie spravodlivosti a férovosti ako študenti iných odborov. Ich rozhodovanie je ale menej altruistické a empatické, pretože menej altruizmu očakávajú aj od iných. Ich „sebeckejšie“ správanie teda nevyplýva z toho, že by mali nižšie štandardy férovosti a spravodlivosti (morálne a hodnotové normy), ale že vychádzajú z iných sociologických noriem a predpokladov sociálnych interakcií.

Z uvedených konštatovaní, resp. záverov vyvstáva otázka, či ekonomické vzdelávanie prispieva aj k väčšej miere rozhodnosti študentov a budúcich ekonómov. Ked’že ekonómia je predovšetkým vedou o vol'be v zmysle využívania disponibilných vzácnych zdrojov, je namieste skúmat', či im štúdium ekonómie dáva dostatočný aparát poznatkov a prostriedkov, aby ich rozhodovanie bolo $\mathrm{v}$ tomto smere čo najefektívnejšie. Úlohou ekonomického vzdelávania je nepochybne aj rozvoj kritickej sebareflexie i reflexie všeobecne z hl'adiska hodnotenia názorov, postojov a rozhodnutí. Zodpovedanie danej otázky nie je jednoduché, pretože rozhodnost' v konaní jednotlivcov vo vel'kej miere závisí od ich osobnostných čít a je t’ažké rozlíšit', do akej miery k nemu prispelo samotné štúdium ekonómie. Určite by však bolo prínosné otestovat' z tohto hl'adiska študentov vo vyšších ročníkoch, ktorí by už mali vediet' rozpoznat', nakol'ko im je ich rozhodnost' prirodzená a nakol'ko k nej prispelo absolvované štúdium. 
Miera rozhodnosti mladých l'udí by sa mala prejavit' už pri výbere zamerania vysokoškolského štúdia. V tejto súvislosti nemožno opomenút' v spoločnosti rozšírený názor, že ekonomické vzdelávacie inštitúcie plnia vo vysokoškolskom priestore podobnú funkciu, akú majú gymnáziá medzi strednými školami, čo znamená, že ich výber na štúdium je skôr výsledkom nerozhodnosti ako jednoznačného a vedomého výberu. Aj táto skutočnost' zrejme prispieva k nelichotivému postaveniu ekonómie a ekonomického vzdelávania $\mathrm{v}$ spoločnosti. Uvedené skutočnosti nás viedli k uskutočneniu prieskumu na vzorke študentov s ciel’om zistit' ich motiváciu na štúdium ekonómie.

\subsection{Výsledky uskutočneného prieskumu}

S ciel'om identifikovat' motiváciu študentov pre štúdium ekonómie, a tým aj zistit' indície vyššie spomínaného selekčného procesu v slovenských podmienkach, sme realizovali prieskum medzi študentmi Ekonomickej fakulty UMB. Najväčšia čast' našich respondentov (55\%) sa úplne stotožňuje s tvrdením, že sa rozhodli pre štúdium ekonómie, pretože poznatky sú využitel'né pre osobné dôvody, napr. pre lepšiu správu vlastného majetku, založenie vlastného podniku a pod. (obr. 1). Takýto výsledok môže indikovat' existenciu selekčného procesu a teda výber ekonomických študijných programov môže prevládat' u jednotlivcov orientovaných na napĺn̆anie osobných (egoistickejších) ciel’ov.

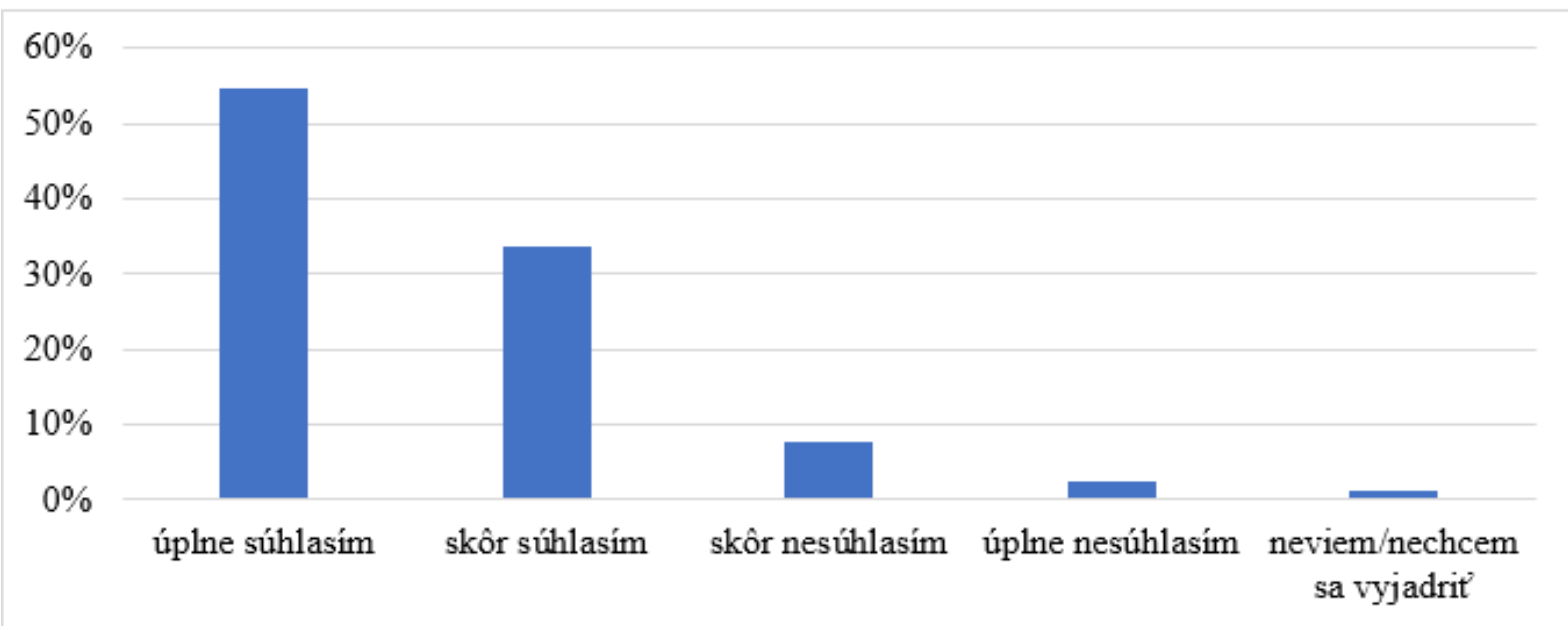

Obrázok 1 Študujem ekonómiu, pretože poznatky ekonómie sú využitel'ne pre osobné dôvody Zdroj: vlastný prieskum, 2021

Druhým silným motivačným faktorom pre štúdium ekonómie v našej vzorke respondentov je skutočnost', že poznatky ekonómie podl'a nich umožňujú lepšie porozumiet' fungovaniu sveta a spoločnosti. Takýto výsledok naznačuje pozitívne očakávania ohl'adom významu ekonomického vzdelávania, ktoré je následne potrebné vo vzdelávacom procese 
podchytit’ a rozvíjat' inovatívnymi metódami výučby ekonómie, aby tieto očakávania boli napĺn̆ané.

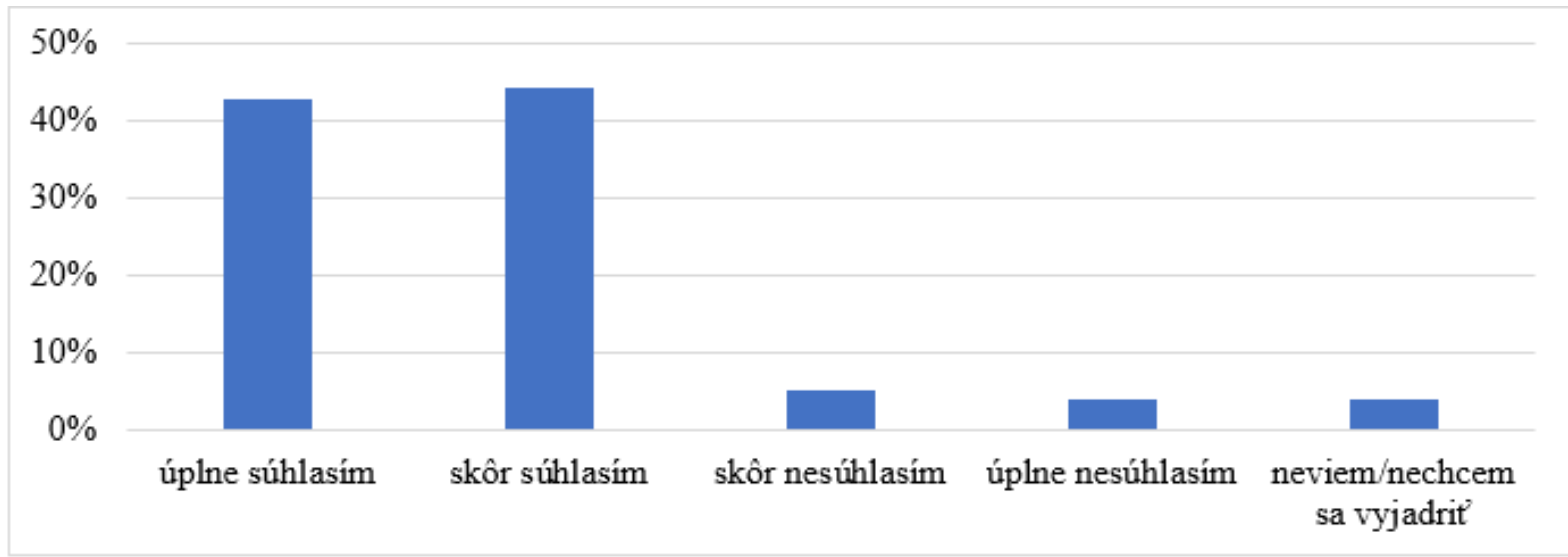

Obrázok 2 Študujem ekonómiu, pretože poznatky ekonómie umožňujú lepšie rozumiet' fungovaniu sveta a spoločnosti

Zdroj: vlastný prieskum, 2021

V porovnaní s prvými uvedenými faktormi motivácie, naše výsledky d’alej poukazujú na to, že respondenti sú relatívne menej presvedčení o schopnosti ekonómie poskytovat' dostatok poznatkov na predvídanie d'alšieho vývoja sveta a spoločnosti (obr. 3), ale aj o vplyve ekonómov na spoločnost' (obr. 4). Tieto výsledky považujeme za zaujímavé z toho pohl'adu, že študenti s predpokladmi machiavelistického typu správania, napr. so sklonmi k manipulácii, si pravdepodobne volia ekonomické vzdelávanie menej často a zrejme sa orientujú sa na iné vedné disciplíny, napr. na politické vedy.

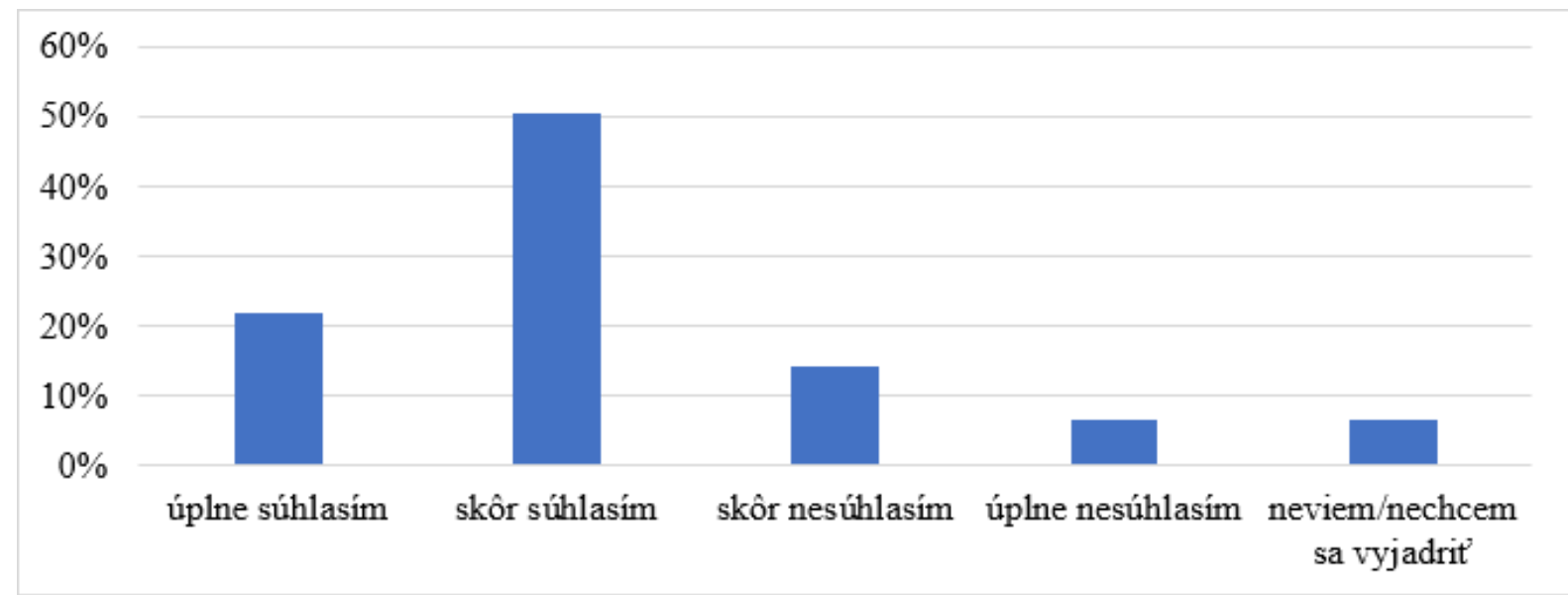

Obrázok 3 Študujem ekonómiu, pretože ekonómovia majú výrazný vplyv na spoločnost' Zdroj: vlastný prieskum, 2021 


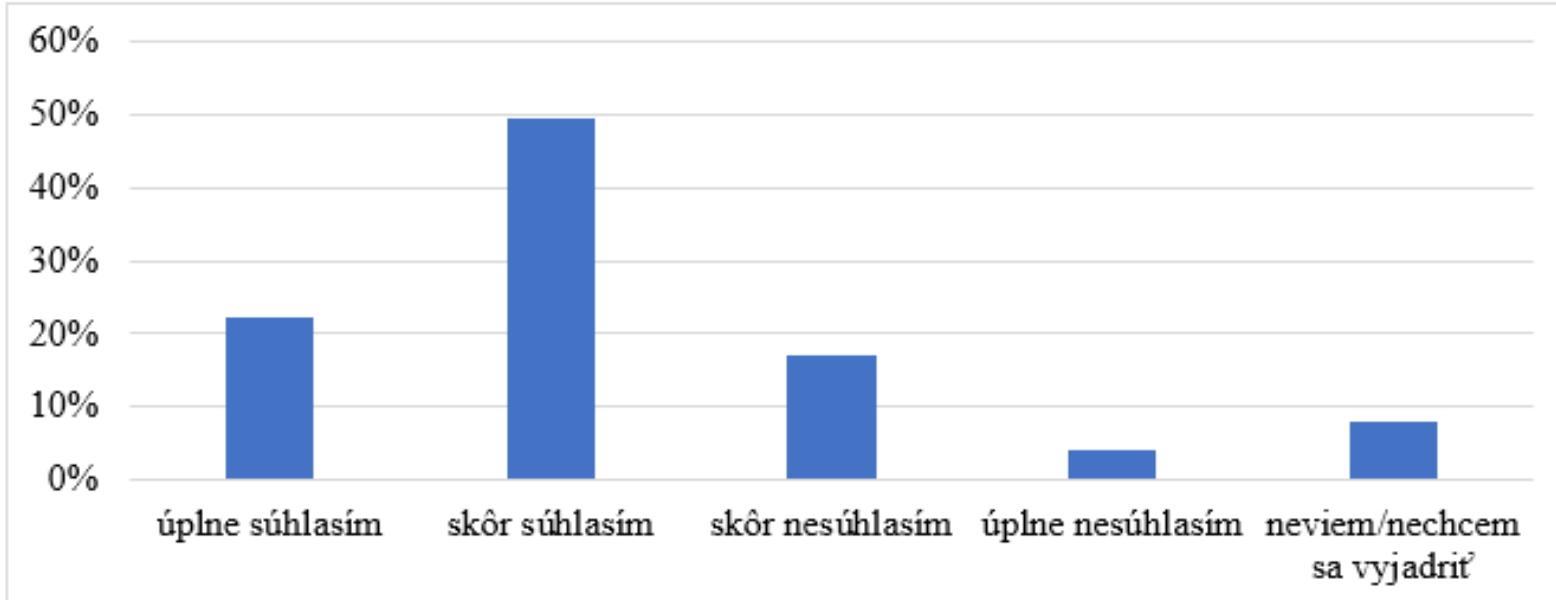

Obrázok 4 Študujem ekonómiu, pretože poznatky z ekonómie umožňujú lepšie predvídat' vývoj sveta a spoločnosti a zmenám sa včas prispôsobit'

Zdroj: vlastný prieskum, 2021

Relatívne umiestnenie d’alšej možnosti motivácie študentov spočívajúcej $\mathrm{v}$ lepšej uplatnitel'nosti absolventov, ako piatej v poradí medzi našimi možnost’ami, pravdepodobne naznačuje menšie sklony k pragmatizmu než sme od študentov ekonómie očakávali, aj ked' s daným výrokom úplne súhlasí 33 \% našich respondentov a skôr s ním súhlasí $55 \%$ respondentov. Naše očakávania vyššieho umiestnenia tohto motivačného faktora vychádza zo záverov predchádzajúcich štúdií (Priščáková, Mertinková, 2021), podl’a ktorých študenti ekonómie už počas štúdia majú vel'ký záujem o vykonávanie platenej práce v súkromnom sektore, aj ked’ ho len zriedkavo vykonávajú v odbore, ktorý študujú.

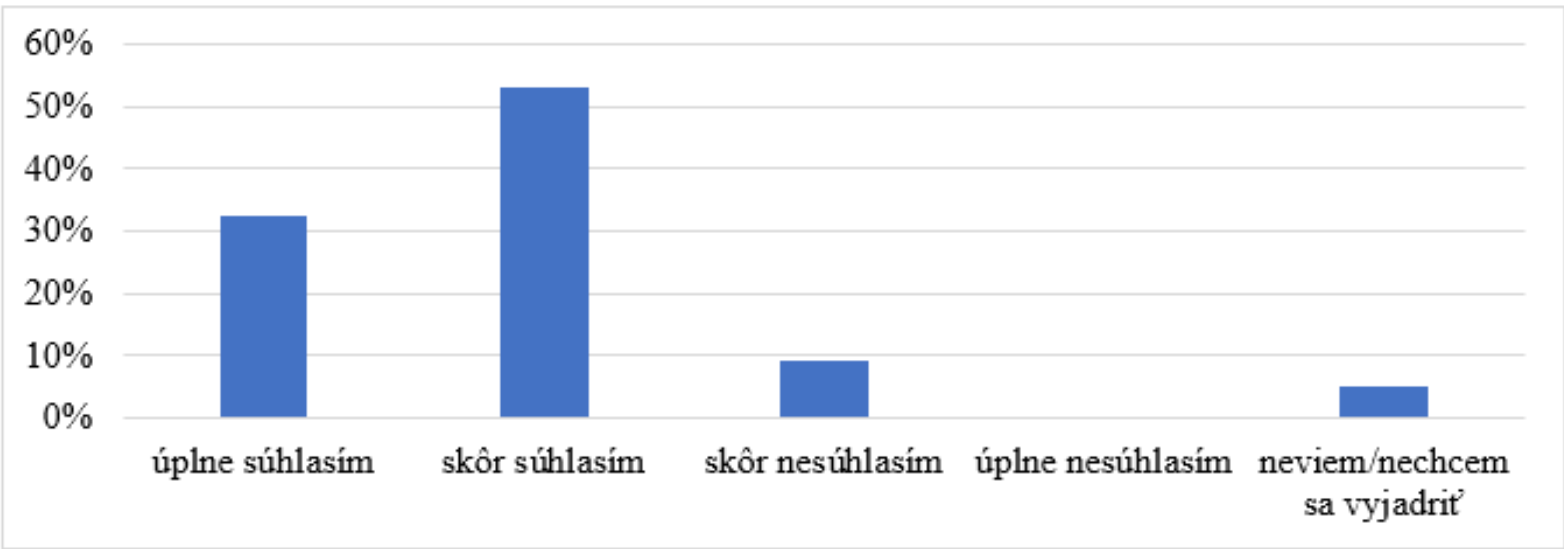

Obrázok 5 Študujem ekonómiu, pretože absolventi majú vel'a pracovných príležitostí Zdroj: vlastný prieskum, 2021

Vzhl'adom k vyššie charakterizovaným názorom o nerozhodnosti študentov ekonomických študijných programov pri výbere vysokej školy, sme do prieskumu zaradili aj hodnotenie výroku, že respondent študuje ekonómiu, pretože si nevedel vybrat'. Viac než polovica respondentov sa s takýmto tvrdením čiastočne alebo úplne nestotožňuje. Na druhej 
strane, pri tejto otázke sa zvýšil počet tých, ktorí sa nevedeli alebo nechceli vyjadrit’ (17 \% respondentov). Všeobecne prevládajúci názor o implikovanej nerozhodnosti študentov ekonómie sa nám na našej vzorke respondentov nepotvrdil.

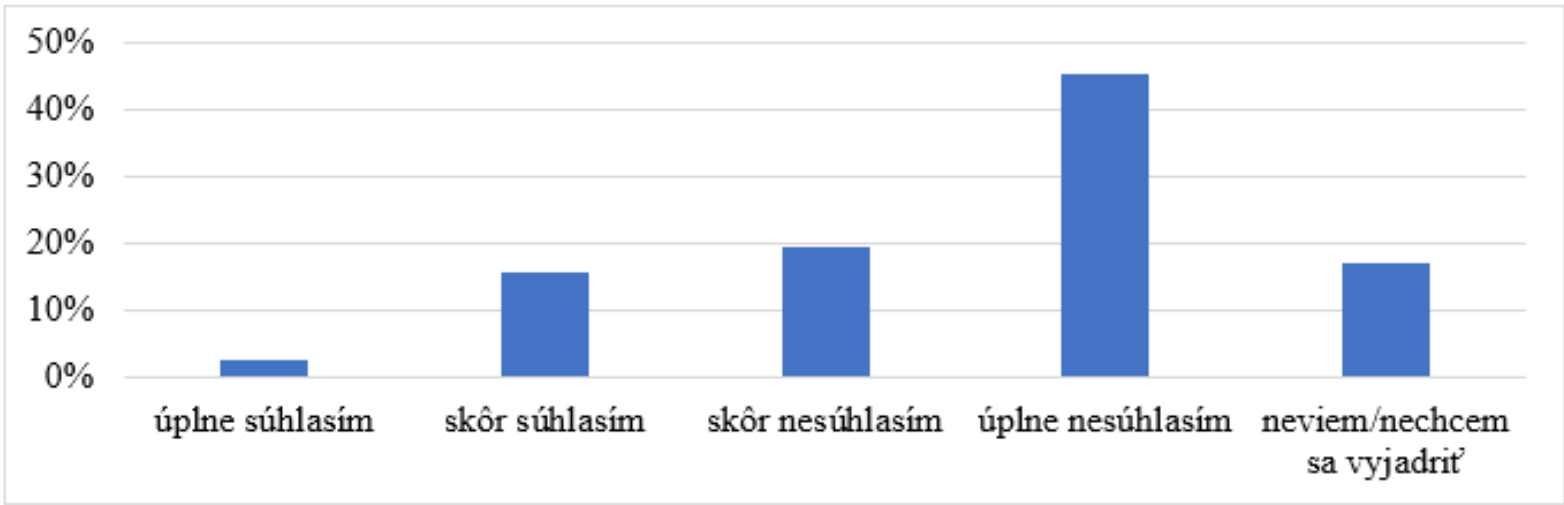

Obrázok 6 Študujem ekonómiu, pretože som si nevedel(a) vybrat' Zdroj: vlastný prieskum, 2021

Ešte jednoznačnejšie vyjadrili respondenti nesúhlas s výrokom, že rozhodovanie o štúdiu uskutočnil za nich niekto iný (rodič, súrodenci, priatelia a pod.). Takmer $60 \%$ respondentov s takýmto výrokom úplne nesúhlasí. Na druhej strane, ide o výrok s najpočetnejšou skupinou opýtaných, ktorí sa nevedeli alebo nechceli vyjadrit’ (25\%).

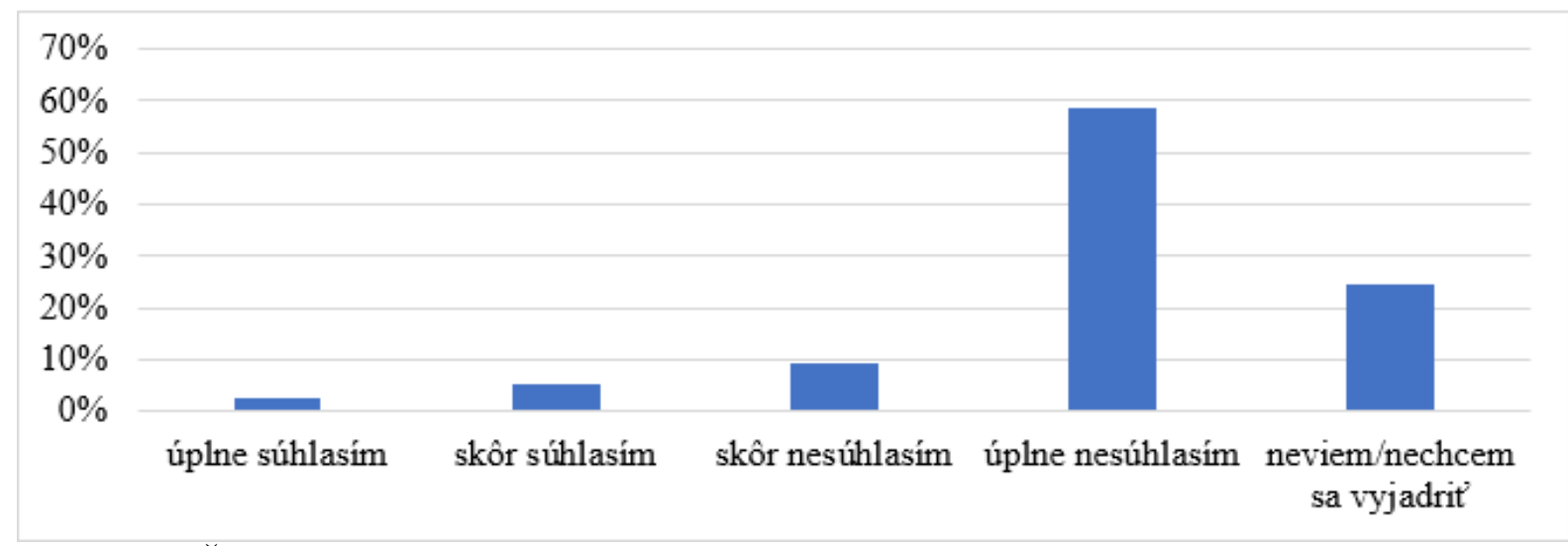

Obrázok 7 Študujem ekonómiu, pretože mi ju vybral niekto iný

Zdroj: vlastný prieskum, 2021 


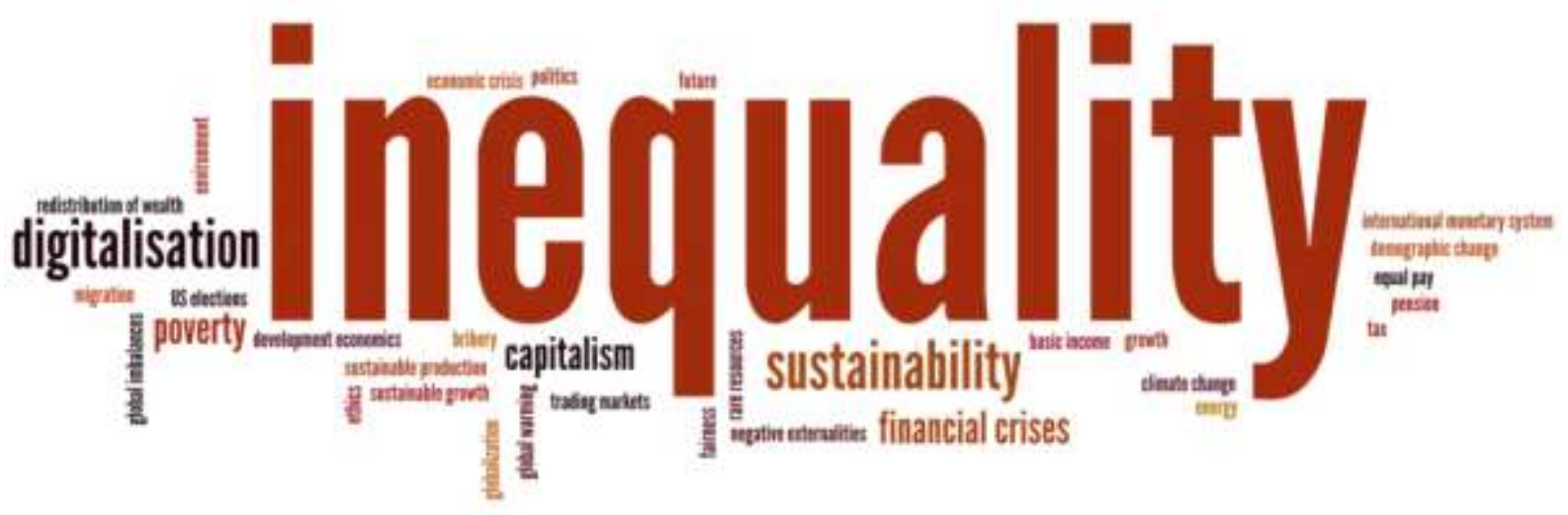

Obrázok 8 Najpálčivejšie témy ekonomického výskumu z pohl’adu začínajúcich študentov ekonómie

Zdroj: The CORE team, 2021, dostupné na https://www.core-econ.org/project/core-theeconomy/

Nadväzujúc na iniciatívu CORE týkajúcu sa zist'ovania toho, aké najdôležitejšie témy ekonomického výskumu študenti ekonómie preferujú (obr. 8), sme túto otázku položili aj našim respondentom. Aj ked' sme si vedomí toho, že začínajúci študenti ekonómie majú len čiastkové informácie a vedomosti o daných problémoch, vychádzame z predpokladu, že preferencia istých tém u študentov ekonómie reflektuje priority spoločnosti i individuálnu motiváciu študentov, a to tak na Slovensku, ako aj v zahraničí. Dosiahnuté výsledky na výberovej vzorke študentov EF UMB ilustruje obrázok 9. Rovnako ako v iných krajinách sveta, naši respondenti pokladajú problém nerovnosti $\mathrm{v}$ dôchodkoch za najpálčivejší. Výsledky nášho prieskumu d’alej ukazujú, že študenti EF UMB prikladajú vel'ký význam hl'adaniu riešení problémov ekonomických a finančných kríz, a následne problematike chudoby a rozvoja ekonomík. Na rozdiel od zahraničných respondentov, slovenskí študenti kladú relatívne menší dôraz na otázky udržatel'nosti a digitalizácie, k riešeniu ktorých by mal aktuálny ekonomický výskum intenzívne prispievat'. 


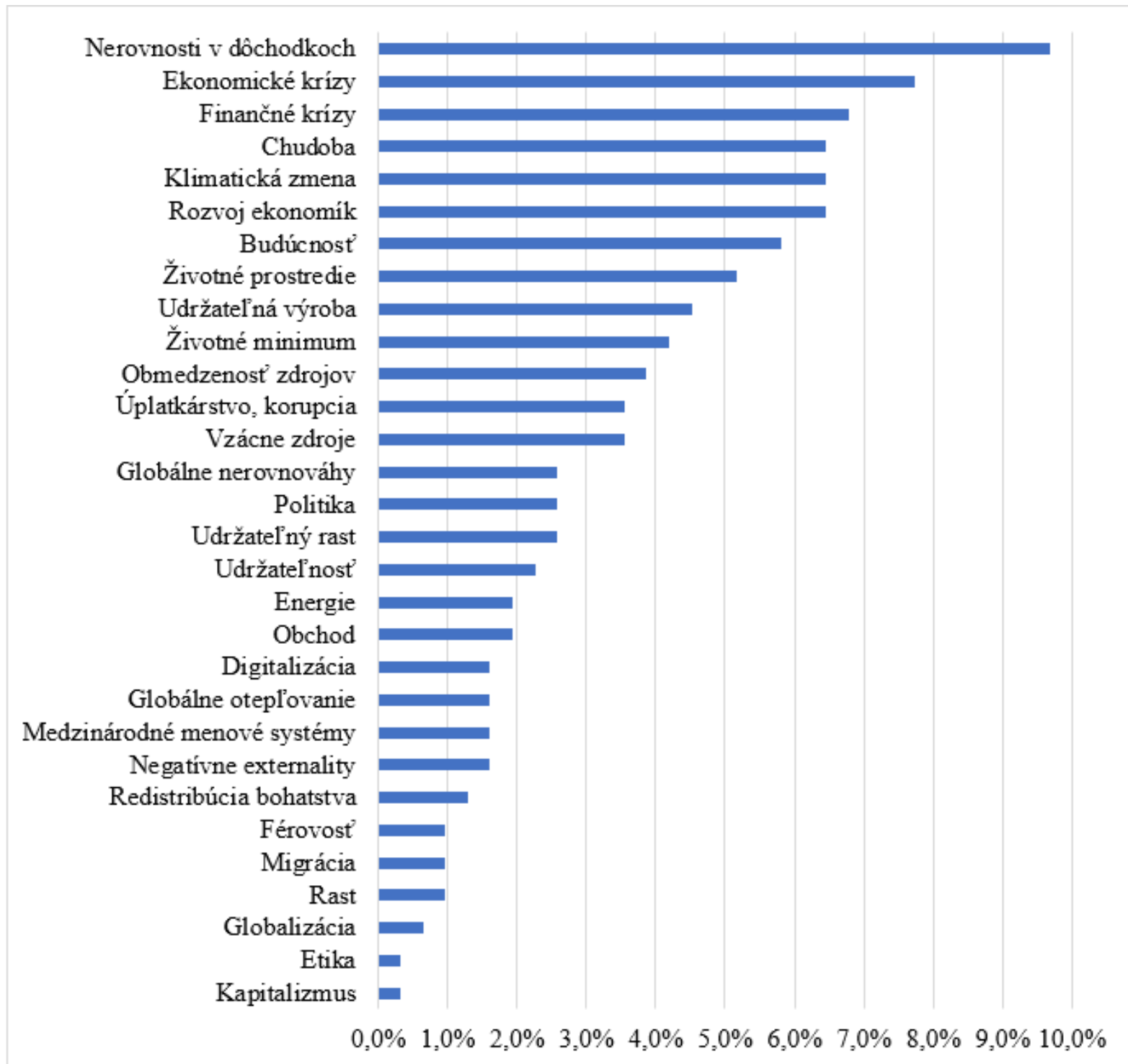

Obrázok 9 Najpálčivejšie témy ekonomického výskumu u študentov 1. roč. na EF UMB Zdroj: vlastný prieskum, 2021

\section{Záver}

Ciel'om príspevku bolo zdôraznit' význam ekonómie ako spoločenskej vedy, poukázat' na dôležitost' jej kontinuálneho poznávania $\mathrm{v}$ ekonomickom vzdelávaní a identifikovat' motiváciu dnešnej generácie mladých l'udí pre toto vzdelávanie. V príspevku poukazujeme na špecifiká ekonómie ako vednej disciplíny vyplývajúce z charakteru jej spoločenskovedného predmetu skúmania, ako aj zo snahy skúmat' tento predmet metodológiou exaktných vied, ktorá sa v ekonómii prejavuje výraznejšie ako v iných spoločenských vedách, a to i napriek potenciálnym rizikám, ktoré daná metodológia predstavuje. Poukázali sme tiež na vplyv historicko-logických súvislostí na vývoj ekonomickej vedy a na neopodstatnenost’ prípadných snáh nenadväzovat' na skúsenosti predchádzajúcich generácií vekonomickom myslení a vzdelávaní, čo históriu ekonomického myslenia redukuje, príp. eliminuje. 
V príspevku sme sa venovali vybraným dimenziám spoločenskej funkcie ekonómie, poukazujeme na jej tri roviny : (1) reálny vplyv ekonomickej vedy na hospodárskopolitické rozhodovanie, (2) reflexiu praktickej hospodárskej politiky v štandardných učebniciach ekonómie a v ekonomickom vzdelávaní a (3) kapacitu ekonómie prispievat' k formovaniu budúcej podoby spoločnosti formovaním kritického myslenia študentov ekonómie. Sú to klúčové skutočnosti, ktorými ekonomická veda prispieva $\mathrm{k}$ sebareflexii spoločnosti a $\mathrm{k}$ obrane jej demokratických hodnôt.

Úspešnost' napíňania vybraných dimenzií spoločenskej funkcie ekonómie závisí nielen od samotného ekonomického vzdelávania, ale aj od motivácie, s ktorou študenti ekonómie vstupujú do vzdelávacieho procesu. Na základe vlastného prieskumu na Ekonomickej fakulte UMB sme identifikovali ako hlavný motív skutočnost', že poznatky z ekonómie respondenti považujú za využitel'né v osobnom živote, čo by mohlo naznačovat' selektívny proces štúdium ekonómie si vyberajú osobnosti s vyššími sklonmi k egoizmu. Tento záver je v súlade so zisteniami Frey and Meier (2002). V danej súvislosti by mohlo byt' zaujímavé preskúmat' i v našich slovenských podmienkach vplyv ekonomického vzdelávania na rozvoj sklonov študentov k egoizmu počas štúdia ekonómie tak, ako to naznačujú skúsenosti zahraničných autorov (Gerlach, 2017), resp. pokúsit' sa identifikovat' aj koreláciu medzi rozhodnutím jednotlivcov študovat' ekonómiu a ich absolvovaným stredoškolským vzdelaním. V d’alšej fáze výskumu by tiež bolo prínosné využit' nástroje psychológie, a to napr. na zist'ovanie postojov študentov a vplyvu ich osobnostných čŕt, či sémanticky diferenciál. Respondenti nášho prieskumu vnímajú úlohu ekonómie sčasti podobne ako respondenti v iných zahraničných krajinách, a to napr. pri riešení problému nerovností v dôchodkoch, ale sčasti rozdielne, pretože nekladú adekvátny dôraz na relevantnost' ekonómie pri plnení potrieb budovania udržatel'ných inovatívnych ekonomických systémov. Tejto aktuálnej výzve dnešnej spoločnosti je potrebné urýchlene prispôsobit' aj ekonomické vzdelávanie na Slovensku.

Grantová podpora: Príspevok vznikol s podporou projektov APVV 0-18-122 „Postavenie sociálnych a humanitných vied v spoločnosti: ich možnosti a limity“ riešenom v rokoch 2019 - 2023 a KEGA 040UMB-4/2021 „Diverzifikácia obsahu a didaktických foriem výučby ekonomických predmetov v slovenskom jazyku a vo svetových jazykoch“. 


\section{Zoznam použitej literatúry}

[1] Bátora, J. (2016). Vrát’me naše spoločenské a humanitné vedy do sveta. Dostupné na https://dennikn.sk/565801/vratme-nase-spolocenske-a-humanitne-vedy-do-sveta/

[2] Bauman, Y., \& Rose, E. (2009). Why Are Economics Students More Selfish than the Rest? []. IZA Discussion Paper Series No. 4625, Bonn: The Institute for the Study of Labor (IZA)

[3] Borrits, B. (2020). Au lieu de sauver le capitalisme, il est urgent d'inventer une autre économie. [Namiesto záchrany kapitalizmu je naliehavé vymysliet' inú ekonomiku]. Dostupné na https://basta.media/crise-economique-capitalisme-chomage-PIB-Banquescentrales

[4] Boyer, R. (2003). L'avenir de l'économie comme discipline. [Budúcnost' ekonómie ako disciplíny]. Alternatives économiques, 57, 60-63.

[5] Carter, J., \& Irons, M. (1991). Are Economists Different, and If So, Why? [Sú ekonómovia iní, a ak áno, prečo?]. Journal of Economic Perspectives, 5 (2), 171-177. DOI: $10.1257 /$ jep.5.2.171

[6] Daniel, J.-M. (2005). Le rôle social de l'économiste. [Spoločenská úloha ekonóma]. Sociétal N 50, 4e trimestre. Dostupné na https://www.decitre.fr/revues/societal-n-50-4etrimestre-2005-le-role-social-de-l-economiste-9782130549567.html

[7] Drábik, J., \& Kšiňan, M. (2017). Chradne a práchnivie slovenská veda? Forum historiae, 2017. Dostupné na: http://forumhistoriae.sk/-/chradne-a-prachnivie-slovenska-veda-.

[8] Delgado, C., Venkatesh, M., Castelo Branco, M. \& Silva, T. (2020). Ethics, responsibility and sustainability orientation among economics and management masters' students. [Orientácia na etiku, zodpovednost' a udržatel'nost' medzi študentmi magisterského štúdia ekonómie a manažmentu]. International Journal of Sustainability in Higher Education, 21(2), 181-199. https://doi.org/10.1108/IJSHE-02-2019-0058

[9] ESET ScienceAward. (2019). Slovenskí vedci v prieskume: Naša práca na Slovenku nie je docenená, no nevzdávame sa. Tlačová správa, Bratislava 16. 04.2019. https://www.esetscienceaward.sk/assets/documents/Nadacia_ESET_Prieskum_medzi_ve dcami.pdf

[10]Frey, B., S., \& Meier, S. (2002). Selfish and indoctrinated economists? [Sebeckí a indoktrinovaní ekonómovia?]. European Journal of Law and Economics, 19(2), 165 171 
[11]Galambaud, B. (2014). Réinventer le management des ressources humaines. [Znovuobjavenie riadenia l'udských zdrojov.]. Ruel-Malmaison: Editions Liaisons. Paris, FR: Wolters Kluwer France.

[12] Galbraith, J. (2003). Les économistes dominants ne contribuent pas de manière intéressante au débat social. [Mainstreamoví ekonómovia neprinášajú do spoločenskej diskusie zaujímavý príspevok]. Alternatives économiques, 57, 60-63.

[13] Gerlach, P. (2017). The games economists play: Why economics students behave more selfishly than other students? [Hry, ktoré hrajú ekonómovia: Prečo sa študenti ekonómie správajú sebeckejšie ako iní študenti]. PLoS One 12:e0183814. 10.1371/journal.pone.0183814

[14]Guerrien, B. (2004). Y-a-t-il une science économique? [Existuje ekonomická veda]. L'économie politique, 4, 97-109.

[15]Ifcher, J., \& Zarghamee, H. (2018) The rapid evolution of homo economicus: Brief exposure to neoclassical assumptions increases self-interested behavior. [Rýchly vývoj homo economicus: Krátke vystavenie neoklasickým predpokladom zvyšuje sebaisté správanie]. Journal of Behavioral and Experimental Economics, 75, 55 - 65.

[16] Juniper et al. 2021. Orthodox macroeconomics textbooks: A critical evaluation using institutional practice as a benchmark. [Ortodoxné učebnice makroekonómie: Kritické hodnotenie využívajúce inštitucionálnu prax ako meradlo]. International Review of Economics Education 37(1):100209, DOI: 10.1016/j.iree.2021.100209

[17] Memorandum spoločenských a humanitných vedcov. Bratislava, 17. 11. - 5. 12. 2016. Dostupné na SME https://blog.sme.sk/mistrik/spolocnost/memorandum-spolocenskychvedcov

[18] Molénat, X. (2009). L'économie, c'est aussi la société. [Aj ekonomika je spoločnost']. Sciences humaines, 2009/9, 16, 2-3.

[19]Ódor, L. (2021). Prispievajú ekonómovia kformovaniu kritického myslenia v spoločnosti? Príspevok prednesený na vedeckom seminári na EF UMB, Banská Bystrica, 8. 10. 2021.

[20] Ondrejkovič, P. (2010). Postavenie vied o spoločnosti v sústave vied. Slovenská politologická revue, 10 (4), 2-21. ISSN 1335-9096

[21]Priščáková, S., \& Mertinková, A. (2021). Uplatnenie študentov Univerzity Mateja Bela s ohl'adom na aktívne nástroje zamestnanosti. Ekonomika a spoločnost', 22 (1), 137-156. doi: https://doi.org/10.24040/eas.2021.22.1.137-156 
[22] Slovenská organizácia pre výskumné a vývojové aktivity (SOVVA). (2021). Z čoho a ako žije veda na Slovensku. Dostupné na Denník N https://dennikn.sk/blog/2252923/zcoho-a-ako-zije-veda-na-slovensku/

[23] Smutný, F. (2020). Vplyv osobnosti manažéra na motiváciu zamestnancov. Ekonomika a spoločnost', 21(1), 16-24

[24] The CORE Team. (2017) The Economy. Economics for a changing world. [Ekonomika. Ekonomika pre meniaci sa svet]. Oxford, UK: Oxford Press.

[25]Wojtkoviak, G. (2018). Profits or Employment: Priorities of Future Managers. [Zisk alebo zamestnanost': Priority budúcich manažérov.]. International Journal of Sustainable Entrepreneurship and Corporate Social Responsibility (IJSECSR), 3 (2)

Adresa autorov: doc. Ing. Jana Marasová, PhD., Ekonomická fakulta UMB, Slovensko, jana.marasova@umb.sk, Ing. Žaneta Lacová, PhD., Ekonomická fakulta UMB, Slovensko, zaneta.lacova@umb.sk 